\title{
Law and economies of arbitration in global tax policy: Indian practice
}

\section{Amit Kumar Kashyap*}

Centre for Corporate Law Studies, Institute of Law, Nirma University, Sarkhej-Gandhinagar Highway, Chandlodia, Gota, Ahmedabad, Gujarat 382481, India

Email: amit1law@gmail.com

*Corresponding author

\section{Pranav Singh Rathore}

\author{
Allahabad High Court, \\ Lucknow Bench, Uttar Pradesh, India \\ and \\ Institute of Law, \\ Nirma University, \\ US-403, Janhit Kunj, Darbhanga Colony, \\ Prayagraj, 211002, Uttar Pradesh, India \\ Email: rathorepranav09@gmail.com
}

\begin{abstract}
Organisation for Economic Cooperation and Development and the G-20 countries introduced an OECD Action Plan aimed at tackling the emerging and challenging issues of base erosion and profit shifting. OECD Action Plan introduced Action Plan 14 which aimed at strengthening the effectiveness and efficiency of the entire MAP process by mandating arbitration if MAP proceedings do not conclude within two years. Considering the specific features of tax disputes, they should be treated differently from the related civil/commercial matters. A unified and global dispute settlement mechanism is very important considering the economics involved in international tax matters but many countries have objected to such unification by relying on aspects such as lack of expertise and sovereignty in tax matters. It is only when the dispute settlement process is strengthened, will any nation, including India, be able to attract the cross-border investment necessary for its overall growth.
\end{abstract}

Keywords: alternative dispute resolution; sovereignty; base erosion; mutual agreement procedure; MAP.

Reference to this paper should be made as follows: Kashyap, A.K. and Rathore, P.S. (2020) 'Law and economies of arbitration in global tax policy: Indian practice', Int. J. Private Law, Vol. 9, No. 4, pp.231-245.

Biographical notes: Amit Kumar Kashyap is the Director of Centre for Corporate Law Studies, at the Institute of Law, Nirma University, Ahmedabad India and Assistant Professor of Law, Institute of Law, Nirma University, 
Ahmedabad. He has MBA LLM from the National Law University, India and Diploma in International Economic Law from the University of Barcelona, Spain. He has a great interest in financial laws, regulations and technology law.

Pranav Singh Rathore is an advocate in Allahabad High Court. He is a BA, LLB (Hons.) graduate from Institute of Law, Nirma University, Ahmedabad with a gold medal in Business Hons. as specialisation. He was keen interest in research and writing and has great interest in international economic laws, commercial tax laws and aviation laws.

\section{BEPS: an introduction}

The issues and challenges arising out of the practice of income shifting within the multinational corporations have attracted global attention over the past couple of decades. ${ }^{1}$ There have been measures aimed at tackling such issues and the recent and arguably the most important of them all is the Organization of Economic Cooperation and Development (OECD) initiative on 'base erosion and profit shifting'. After the meeting in Mexico in 2012 June, the G-20 leaders decided that there is a need to prevent base erosion and profit shifting and that the leaders will follow with attention the work and initiatives taken by OECD in this regard. Subsequently, an OECD report was published in February 2013 which was finally followed by the action plan (OECD Action Plan) in July of 2013. ${ }^{2}$ Subsequently, in 2017, 68 developing countries signed the Multilateral Convention to Implement Tax Treaty Related Measures to Prevent BEPS ('MLI'). ${ }^{3}$ This convention is an attempt to tackle base erosion and profit shifting through tax planning strategies which exploit the gaps in the tax rules to artificially shift profits to low/no tax locations and also modifies a large number of bilateral treaties entered into by these countries.

\subsection{BEPS Action Plans}

This action plan identifies 15 actions which are based on three pillars, firstly, coherence in the domestic laws and rules which affect cross-border activities, secondly, reinforcing the substance requirements in the prevailing international standards and thirdly, improving the aspects of certainty and transparency in the global regime. ${ }^{4}$ Before this action plan was introduced, Article 25 of the OECD Model Tax Convention ${ }^{5}$ provided for a mechanism, which was independent from the ordinary legal recourses and remedies as available under the domestic laws, under which the competing authorities as appointed by the relevant State Governments, may resolve the disputes and differences arising out of the interpretation or application of any law, rule or convention on a mutually agreeable basis. This mechanism, known as the mutual agreement procedure (MAP), is important for the proper application and interpretation of the tax treaties by ensuring that the taxpayers are entitled to the benefits of the treaty and are not subjected to such taxation, by either of the countries, which is not as per the terms of that treaty. ${ }^{6}$ 


\subsection{BEPS and MAP procedure}

The MAP procedure, used by the majority of the countries, has certain limitations. This procedure can reach a conclusion only if both the parties come to a mutually agreeable solution based on their good faith consultations. This procedure fails to provide for a situation wherein consultations do not lead to an agreement. ${ }^{7}$ This has created long procedures and a huge backlog of unresolved cases and dissatisfied taxpayers. These facts led to discussion aimed at improving the dispute settlement process by satisfactorily resolving this backlog of unresolved cases. Considering such issues and keeping in mind the OECD initiatives, BEPS Action Plan 14 was introduced which aimed at developing various solutions to tackle the obstacles which prevent the countries from resolving their treaty-related disputes under the MAP, including the absence of any provision for arbitration in most of the treaties and the fact that access to MAP and arbitration may be denied in certain cases. ${ }^{8}$ This plan was introduced for eliminating opportunities for cross border tax avoidance and evasion practices and for building an effective system of dispute resolution in the international tax matters, which supports economic growth and a prospering global economy.

The measures introduced under Action Plan 14 aim to strengthen the effectiveness and efficiency of the entire MAP process. ${ }^{9}$ These measures aim to minimise the risks associated with uncertain and unintended double taxation events by ensuring a consistent, uniform and effective implementation of tax treaties, including the effective and timely resolution of the disputes relating to the matters of interpretation or application of the tax treaties, based on the MAP. The OECD's Report on BEPS Action 14 has introduced an in-built state to state arbitration mechanism in the tax treaties which would prevent extending MAP settlement beyond two years, after which the arbitration clause shall be invoked. Action Plan 14 recognises the importance of removing the issue of double taxation for the efficient growth of cross border trade and investment and reflects upon the commitment of countries to implement a minimum standard which ensures that the treaty-related issues and disputes are resolved in a timely and effective manner. These minimum standards, as set out in Action Plan 14, seek to achieve certain objectives for ensuring an effective dispute resolution process, such as:

- countries/contracting parties should ensure that the treaty obligations related to MAP are implemented in good faith and that the MAP cases are solved in a time efficient manner

- countries/contracting parties should ensure that the administrative/internal processes promote the prevention and timely resolution of the treaty-related disputes

- countries/contracting parties should ensure that the taxpayers who meet the requirements specified under paragraph 1 of Article 25 of the OECD Tax Convention ${ }^{10}$ have access to the MAP within their jurisdiction. ${ }^{11}$

\section{Dispute settlement mechanism in international tax disputes}

Disputes, as shown throughout history, are a common feature of any human society. Such disputes arise regardless of time, society, social traditions of the level of development. Thus, taxation disputes are also a common feature of any modern tax system around the 
globe. But, tax disputes deserve special attention because the tax laws, especially income tax laws, are more complex than civil or commercial laws and have substantially more impact on the economy around the globe. Moreover, there is a reversal of role in tax disputes, as compared to civil disputes, as and when they are considered by the tribunal or the courts. Unlike the majority of the civil or commercial cases, tax disputes involve an asymmetry or a difference in the bargaining powers between the parties concerned and the parties are, generally, unequally positioned. ${ }^{12}$ These factors highlight that tax disputes deserve special attention as compared to other civil/commercial disputes. ${ }^{13}$

Over the last three decades, arbitration and other means of alternate dispute resolution (ADR) mechanisms have accumulated huge interest as a means for resolving the international taxation and other taxation related issues. These ADR mechanisms are said to be very handy when it comes to resolving tax disputes as they reduce the time and costs involved in resolving disputes. ADR also increases the possibility of settlement, thereby increasing the satisfaction amongst the disputants with the outcome of the issue and the manner in which the issue is resolved. Moreover, ADR also leads to increased instances of compliances by the parties to the mutually agreed settlement.

Considering the complexities of the issues related to taxation and keeping in mind the advantages of the dispute settlement mechanisms, i.e., ADR, there have been many instances in the past wherein a dispute settlement mechanism was proposed and implemented for resolving International tax disputes. Pre-World War I, there was a prevalence of dispute resolution in tax treaties as a non-binding process based on negotiations between the states on specific issues. More than 80 treaties were entered into between WWI to WWII aimed at preventing double taxation of income, wherein dispute resolution was a process based on negotiations. ${ }^{14}$ One such example was the 1922 Treaty of Rome, which provided taxpayers with a right to petition for the purposes of initiating consultations between the governments. ${ }^{15}$ Subsequently, the 1926 UK-Irish Free State Income Tax Treaty and the 1934 Succession Duties Convention, provided, for the first time, for a binding and mandatory dispute resolution process between countries and taxpayers. Subsequently, the 1989 United States-Germany Income Tax Treaty was the first bilateral treaty which adopted a provision for arbitration between the two countries over international tax matters. ${ }^{16}$ The United States, subsequently, entered into a lot of bilateral treaties which contained an arbitration clause. But such methods were introduced on an experimental basis and were restricted to issues of technical nature. Subsequently, another major development took place in 1990 with the introduction of the European Arbitration Convention, wherein twelve major European countries signed this agreement for eliminating double taxation in connection with the matters of adjustment of the profits of associated enterprises. ${ }^{17}$ This convention introduced a mandatory arbitration clause subsequent to the two-stage MAP clause between the parties but had several limitations and was not globally accepted.

These historical developments were very important and provided the impetus for the growth of a global process aimed at ensuring the protection for the countries as well as its taxpayers. These developments were carried forward by OECD through its initiatives, which eventually led to the introduction of the BEPS Action Plan 14, aimed at strengthening the MAP by introducing dispute settlement mechanisms in the disputes involving questions of taxation. The authors will now understand the economics or the need for dispute settlement mechanism in the disputes involving questions of International Tax. 


\section{Economics of dispute settlement in international taxation}

International tax treaties are generally designed to remove the trade barriers to investment, to international trade, to increase world productivity and to develop healthy international relations. ${ }^{18}$ Considering this, tax treaties include a variety of provisions which allocate taxing rights between the signatories including the procedure to resolve tax disputes. This procedure was generally through the MAP as already elaborated above. Article 25 was drafted to deal with three kinds of issues, namely, issues involving grievances of taxpayers regarding the specific application of the treaty, issues involving difficulties and doubts regarding the interpretation and application of the treaty and issues regarding the elimination of double taxation in cases not dealt with by the treaty. ${ }^{19}$ But this mechanism had its limitations, as already elaborated, and led to many unresolved issues between the countries or the taxpayers and the countries.

These unresolved international tax disputes can act as a significant barrier to the expansion of the cross-border trade and investment between the countries. ${ }^{20}$ Keeping this in mind, it becomes imperative to ask why all the stakeholders involved in the tax system, including the government, should turn their attention towards establishing a uniform dispute settlement processes for resolution of the international tax disputes. Some of the reasons why a uniform dispute settlement process is the best solution for resolving the tax-related question are as follows:

- The principles governing income allocation are changing significantly in this era of globalisation. The principles and concepts of transfer pricing and other related standards are also undergoing changes as per the economic realities of the modern world. These rules will develop the capacity of countries to attract revenue from other countries which will inevitably lead to disputes between them. In such cases, the business is stuck in the middle and it remains in the best interest of all that these disputes do not remain unresolved due to conflicts between the countries.

- Countries, today, seek revenues in the form of tax from the businesses operating in their jurisdiction and within their economy, even if there are disagreements about the level and type of business justifying such taxation.

- Every country has the ability to challenge and modify the tax planning strategies which provide inadequate revenues for their finances. The inefficient dispute resolution processes slow down the capability of the states to solve such challenges.

- Businesses look to minimise their tax costs by, sometimes, involved in tax avoidance strategies, which can be challenging for countries.

- The citizens and all the stakeholders need to be confident that their tax system is efficient, transparent and fair for it to attract investment and cross-border trade.

- The cross-border disputes take years to resolve, thereby consuming a lot of resources from all the stakeholders involved.

- The general view regarding the existing dispute settlement mechanisms in international taxation is that these are not working effectively. Such a perception decreases the confidence of the investors and is reflected by the increasing number of MAP requests being filed and the ever increasing number of the unresolved MAPs. 
- $\quad$ There is an issue of secrecy built into the MAP process, which makes access to data scarce, especially for the non-OECD members and countries. This leads to insufficiency of data and information asymmetry between the countries. Countries should provide more data, focusing on the effectiveness of the MAP, for resolving the concerns of the stakeholders involved in the global tax regime.

- Many countries are unaware about the number of unresolved cases by MAP and the continuation of status quo is not an attractive option for the stakeholders involved in the global tax systems. Countries should examine ways for avoiding/resolving the disputes in the manner which is consistent for the developed as well as for the developing countries.

- Finally, the establishment of a uniform and efficient tax dispute resolution mechanism will be in the interest of all the parties. Such an establishment would require time and cooperation at a global level while keeping in mind the varying interests of the countries.

Considering such issues and problems, it is very important to have a uniform and effective mechanism for the resolution of tax-related disputes. Considering the importance of tax revenues and cross-border trade and investments towards the growth of any economy, it is important that their disputes are resolved in a timely manner. Effective dispute resolution by the competent authorities (CA) under the tax treaties is a very crucial factor for ensuring good faith implementation of the tax treaties. ${ }^{21}$ This was one of the major impetuses behind the introduction of Action Plan 14. Effective cross border tax dispute resolution is essential in today's globalised society but despite this, there are certain challenges and issues being raised by various countries, including the G-20 countries, against the mandatory nature of the Action Plan 14. Such issues and challenges against the idea of mandatory arbitration in international tax disputes will be dealt with by the authors in the next chapter.

\section{Issues and challenges to the dispute settlement mechanism in international taxation to India and the world}

The MAP, as it exists, does not require the countries to reach an agreement, but to try their best in reaching to such an agreement. ${ }^{22}$ This resulted in a backlog of cases, thereby encouraging OECD to favour mandatory binding arbitration. ${ }^{23}$ There have been many issues and challenges raised by many countries against the idea of incorporating mandatory arbitration in disputes related to the questions of international taxation. The inclusion of MAP without arbitration in the OECD Model Tax Convention reflects the general reluctance towards arbitration by the developing countries, considering their limited experience and lack of familiarity with this ADR mechanism. ${ }^{24}$ Countries have even objected to the lack of knowledge and expertise of the third party arbitrators, who will be unaware and ignorant about the policies and rules of the countries, thereby potentially affecting their legal regime and public policies. Countries have also raised numerous concerns regarding the neutrality of the arbitrators and other policy-related issues which might arise due to the third party adjudication of the disputes concerning the policies and interpretation of a statute of a particular state. Other concerns and objections, as raised by many countries, relate to the high cost of arbitration and the unequal/ 
asymmetrical impact of that on the developing countries, as well as the perceived limitation of the 'sovereignty' of the country arising due to the mandatory arbitration clause in the MAP procedure.

The most commonly raised issue when discussing any form of binding ADR, but in particular mandatory binding arbitration, is what is often termed the impact on 'sovereignty'. ${ }^{25}$ Countries are considered to be sovereign in matters related to tax, however, in practical terms, it is somewhat constrained by the rules, actions and policies of other countries that impact or have the potential of causing an impact on their tax system in an increasingly global world. Countries seek to encourage cross border trade and investment by signing various double tax treaties and agreements but also look to ensure the collection of tax revenue where the value producing profit is created. This act of agreeing to international law, by implementing it in domestic laws, to act in a certain way, creates limitations on how a government can act in future thus affecting the sovereignty in a certain way by its self-inflicted actions. As per the United Nations Secretariat Paper on ADR in taxations, there are three possible sovereignty objections, which the countries usually refer. ${ }^{26}$ These are first, unconstitutionality wherein countries may have constraints in terms of their constitutional provisions. Their laws may not allow them to implement tax arbitration. Secondly, such provisions may be constitutional but with unfeasible consequences, wherein the inclusion of an arbitration provision might be constitutionally valid but may entail unconstitutional consequences. Thirdly, issues of sovereignty in a more generalised sense, wherein countries are concerned about shifting the decision making from itself to an entity that might lack in experience and thus they invoke the sovereignty argument to ensure that they do not lose control over tax revenues and the resulting dispute resolution process. ${ }^{27}$

Leading nations have been reluctant to agree to a mandatory resolution of disputes. The United States of America, for instance, declared their issues with the General Agreement to Trade in Services (GATS) stating that these were in direct conflict with the US's national laws as well as bilateral agreement conventions. The issue was the rule wherein any discrimination attracted the mandatory dispute resolution process as per the WTO dispute settlement rules. Considering the reluctance shown by a leading nation, a compromise was subsequently reached and the agreement was amended accordingly. ${ }^{28}$

These are certain issues which have persisted against the idea of mandatory dispute settlement in international tax matters. The authors will now focus on the Indian scenario and will analyse the reaction of the Indian Government and authorities to the idea of mandatory arbitration in tax disputes.

\section{India and tax treaty arbitration}

India has shown its reluctance towards the by-default inclusion of the mandatory arbitration clause, thus it remains an optional provision even within the model of the UN. The Government of India, as well as other developing countries, faces pressure from the stakeholders for taxing the cross-border income, but they bear the brunt of the inequitable allocations from the tax treaties, which majorly fail to reflect the aspirations of the developing countries. ${ }^{29}$ India today stands as an active litigant in various cross-border tax disputes, which affect the economy negatively and also hampers the confidence of the investors. 
The performance of an economy, engaged in international business and transactions, depends majorly on a non-cumbersome exit mechanism and an efficient dispute resolution mechanism. The current domestic dispute resolution mechanism in India, e.g., under the tax laws, are very limited in scope. There is no mechanism for mutually settling upon a basic fine, with the law merely allowing reducing the imposed penalties and other interests, if charged. Moreover, the option of appeal is also very limited in scope. Add to this the pendency of a huge number of cases and the situation gets even worse. The recently constituted Tax Reforms Commission under Parthasarthi Shome, in 2016, also focused on these aspects for strengthening the tax-related adjudication in India, which is essential for building the confidence of investors.

This grass-roots problem of the prolonged continuation of tax disputes, lack of clarity in the application of laws coupled with the unilateral demands made by the concerned departments has made India being infamously perceived as non-tax friendly country. ${ }^{30}$ India has around one hundred tax treaties in force. All of these treaties provide for MA, but not even a single one of them contains the provision related to arbitration to supplement such MAP. Such exclusion by India rests on two arguments, i.e., it hampers the sovereignty and it goes against the principle of equality for the domestic taxpayers as provided for under Article 14 of the Constitution.

The existing MAP framework suffers from various limitations such as the objections raised by the taxpayer must be justified in the eyes of the competent authority and countries are only obliged to endeavour to resolve treaty dispute instead of being obliged to resolve such disputes. Not just this, there no specific timeline for resolution of disputes through MAP which results in taxpayer annoyance and unnecessary delay. ${ }^{31}$ The OECD's Report on BEPS Action 14 has made an effective resolution in this regard by introducing an in-built state to state arbitration mechanism in the tax treaties which would prevent extending MAP settlement beyond two years, after which the arbitration clause shall be invoked. The debate regarding tax treaty arbitration in India has been subjected to the sovereignty argument that it would limit the government's sovereign control over taxing foreign companies. ${ }^{32}$ Therefore, it is important to examine whether such an argument is valid and to what extent.

MAP has featured in most of the tax treaties, albeit with circumstantial variations, for resolving international tax disputes in an effective manner. The OECD'S Report on BEPS Action 14, by introducing a mandatory and binding arbitration clause, aims at improving this already established dispute resolution mechanism involving MAP cases. Many countries, including India, have expressed reservation on the mandatory and binding approach which the report adopts towards dispute resolution mechanism. ${ }^{33}$ India and other developing countries are of the opinion that such an approach hampers the sovereign right of countries in taxation and even limit their abilities to apply the domestic laws for taxing or dealing with non-residents and foreign companies. ${ }^{34}$

After the OECD Report was published in October 2015, India stood upon its stance and decided not to turn up as one of the 20 countries that gathered to commit to the improved MAP arbitration. ${ }^{35}$ Governments, globally, have made a number of efforts aimed at changing the taxing regime for the MNCs. After India was taken to the International Centre for Settlement of Investment Disputes (ICSID) by Vodafone, Cairn and Nokia for tax-related disputes, the government decided to amend its investment treaties, pulling taxation matters out of the ambit of treaty-related dispute settlement mechanism, stating that such matters formed an integral part of the state's sovereignty. ${ }^{36}$ 
The concern of various countries regarding the breach of sovereignty is misplaced. Firstly, despite being a mandatory and binding process it is not automatically applied and applies only when countries fail to reach an agreement under MAP settlement within two years. The fact that such deadlines involving MAP settlement are not found in tax treaties cannot be used as an excuse for delay considering that the countries have an obligation to prevent instances of irregular taxation swiftly. Secondly, the result of the process depends entirely upon the resolution submitted by both parties. Thirdly, countries are even given liberty to mutually agree upon the procedure of the entire proceedings. The rules also ensure that the panel so formed is chaired by a national or a resident of either of the parties which are a party to the proceeding.

Considering the above-mentioned points it is not fair to presume the alleged biasedness of the arbitration panel so constituted. The panel neither represents any sovereign nation nor does it exercise any sovereign authority of its own. Further, countries may even dismiss arbitration proceedings if the dispute gets resolved by MAP any time prior to the arbitration decision. The countries are given an option not to implement the decision of the panel if an alternative arrangement is made in a timely manner. The binding and mandatory arbitration is proposed to serve as an effective deterrent for the countries to ensure that they settle on the MAP settlement in a time-bound manner. ${ }^{37}$

Article 14 guarantees equality but permits reasonable classification. The Supreme Court had stated in the case of State of Kerala v. Haji Kutty Naha (AIR 1969 SC 378) that imposition of uniform taxation norms on dissimilar transactions is in itself discriminatory. Residents and non-residents are not in similar positions suitable for comparison. Thus, the argument of unconstitutionality against initiating arbitration fails.

The judiciary has to play a crucial part in the process of incorporating arbitration within the global tax treaties and the recent Delhi High Court Judgment in the famous Vodafone Case is a perfect example of that. The judge ruled against the Indian Government's demand for an anti-arbitration order, forcing the government to face two Bilateral Investment Treaty Arbitration proceedings against Vodafone. The question before the court was to decide on the jurisdiction of the domestic courts on issues arising out of the BIT arbitrations. The court stated that the domestic courts are not completely ousted from the matter, but the court stated that the ultimate authority on resolving the issue of double arbitration is the tribunal itself and that the domestic courts should apply self-restraint. ${ }^{38}$ The court even declared that the Arbitration and Conciliation Act of 1996 does not apply to BIT Arbitrations by its own force (Proprio vigore). ${ }^{39}$

In NHAI v. M/S. Bsc-Rbm-Joint Venture, the court had upheld the award of the arbitral tribunal noting that the tribunal was the final judge on the facts and the legal issues involved. These judgments have been construed as signalling that India is on its way of becoming an arbitration-friendly country.

The current government has repetitively voiced its commitment to the BEPS project and has taken steps in accordance with it. For instance, the government proposed a test regarding place of effective management to examine tax residence of companies, it amended tax treaties with Cyprus, Singapore and Mauritius to curb abuse and prevent round-tripping of funds following BEPS Action 6, it introduced country by country reporting requirement as per BEPS Action 13 for the large companies and the list continues. These measures will unavoidably attract uncertainty for taxpayers, resulting in unintentional double taxation in some cases. ${ }^{40}$ This issue can be taken care of, if while 
incorporating BEPS project, simultaneously steps are to be taken to strengthen the dispute resolution mechanism within the tax treaties, i.e., the MAP framework.

\section{Recent initiatives and way forward}

Arbitration and other forms of ADR mechanisms have a useful role in effectively resolving international tax disputes, but it is very crucial that confidence is built and developed in such mechanisms. We need to develop them as global solutions that can work well for developing as well as for developed ones. The main challenges lie in the fact that such solution would need to address the legitimate concern of certainty and uniformity, while at the same time respecting the different viewpoints, situations, development and priorities of various countries.

The Indian parliament recently passed the Arbitration and Conciliation (Amendment) Bill, 2018 to improve the arbitration regime, especially the institutional arbitration in India. Through this bill, the government aims to establish an Arbitration Council of India, which shall be the grading authority for the arbitration institutions and other forms of alternative dispute mechanism forums. The appointment of arbitrators for International Commercial Arbitration will be supervised by the Supreme Court and for other matters by the High Courts. This will ensure that the issue of lack of familiarity with the process and knowledge is tackled.

Moreover, the government also recently passed a bill for creating an International Arbitration Centre at New Delhi. This bill also aims at improving the regime for institutional arbitration in India and aims at establishing India as the hub for institutional arbitration. These recent initiatives by the government highlight the focus that it is placing on the importance of arbitration for the economy. A healthy arbitral institution will ensure that investors are attracted to invest in India.

For establishing an inclusive and successful arbitration regime it is very necessary that this global solution delivers equal access to justice between rich and poor countries and between countries which are experienced in arbitration and countries which are inexperienced in it. These qualities must not just be present in the system, but should also be seen to be present for an effective system to successfully exist. The various issues involving cost and time can be resolved by introducing time and cost control mechanisms. The MoU between the US and Canada is one of the major examples of such a mechanism. The countries clearly decided a timeframe for the arbitral proceedings and also allocated costs to the same. Moreover, to avoid cost complexities, the parties can set out their payment division beforehand in their agreement. Also, as per the report of the United Nations, a mechanism can be established wherein the same panel may be asked to hear a number of different cases involving same or similar issues, which will very effectively solve the issue of the huge backlog of cases. Also, the issue of expertise and familiarity can be resolved by institutionalising the entire arbitration process.

A close study of India's MAP program suggests that it needs reform. India lacks any MAP guidance and it does not publish annual statistics on MAP program and hence MAP program remains unclear and lacks transparency. To draw some idea about India's MAP progress, a review of the annual reports published by the Finance Ministry on its website for the last few years discloses that India has MAP inventories with some countries but no information is available on how many cases were taken up for resolution and with respect to which country. There is the absence of any specific information on India's 
MAP program like kind of disputes they relate to, date of filing cases, the time period required to resolve the disputes, details of progress achieved in MAP meetings conducted so far, details of delayed cases of resolution and so on. The lack of data with respect to resolving MAP cases presents a dreary account of India's MAP program, which should be streamlined in accordance with international best practices. ${ }^{41}$ Further, as per BEPS Action 14 minimum standard, there is a need for publication of detailed guidance on the MAP program which a taxpayer is required to submit with a request for MAP assistance as well as the publication of annual MAP statistics as the existing MAP framework is not effectively transparent. The mandatory and binding arbitration clause in the tax treaties will instil confidence among foreign investors that India has committed to avoiding double taxation not only in law but also in spirit. ${ }^{42}$

Some practical issues which can arise with regards the mandatory arbitration in global tax disputes in India are related to the cost involved and the lack of resources available to sustain the shift of the pending MAP cases to arbitration. Other issues which can arise are related to transparency and equality in treatment in the arbitration proceedings. The solution for India lies in resolving these issues via negotiations and not in denying the arbitration completely. Despite recording huge rise in the ease of doing business index, India still falls behind in enforcing contracts, which needs to change if it aims at a global leader and also for becoming a global hub for arbitration.

The continuity of India's economic development depends on a growth-friendly economy, which depends on tax certainty and an effective tax dispute resolution mechanism. MAP framework plays enabling role in international tax dispute settlement. In fact, such a framework would allow India to nurture greater investor confidence which has been affected greatly due to unending transfer pricing disputes. As already pointed out above, changes brought out as per BEPS project particularly changes to the transfer pricing rules will definitely result into greater tax disputes and in such situation, it is imperative to strengthen dispute resolution within two years through MAP and thereafter through arbitration if required. The objective should be building investor trust in the international tax treaty framework.

\section{References}

Altman, Z.A. (2006) Dispute Resolution Under Tax Treaties, IBFD Publications, Amsterdam, the Netherlands.

Arnold, B.J. (2015) An Introduction to Tax Treaties, United Nations Documents [online] http://www.un.org/esa/ffd/wp-content/uploads/2015/10/TT_Introduction_Eng.pdf.

Bakker, A. and Levey, M.M. (2011) Transfer Pricing and Dispute Resolution, IBFD, Amsterdam, The Netherlands.

Cheng, T-H. and Entchev, I. (2014) 'State incapacity and sovereign immunity in international arbitration', Singapore Academy of Law Journal, Special ed., Vol. 26, pp.942-974.

Committee of Experts on International Cooperation in Tax Matters, Tenth Session (2015) UN Secretariat Paper on Alternative Dispute Resolution in Taxation [online] http://www.un.org/ esa/ffd/wp-content/uploads/2015/10/11STM_CRP8_DisputeResolution.pdf (accessed 18 September 2018).

Dasgupta, A. and Thakurta, P.G. (2018) The Vodafone Tax Saga and India's Arbitration Worries NewsClick, NewsClick [online] https://www.newsclick.in/vodafone-tax-saga-and-indiasarbitration-worries (accessed 23 March 2019). 
Deloitte (2016) OECD Issues Guidance on Action 14 Peer Reviews, Global Transfer Pricing Alert [online] https://www2.deloitte.com/content/dam/Deloitte/tw/Documents/tax/beps/twinternational-alert18.pdf.

Dharmapala, D. (2014) What Do We Know about Base Erosion and Profit Shifting? A Review of the Empirical Literature, CESIFO Working Paper No. 4612, Leibniz Institute for Economic Research.

EY Global Tax Alert (2017) India Signs Multilateral Convention to Implement Tax Treaty Related Measures to prevent BEPS [online] https://www.ey.com/gl/en/services/tax/internationaltax/alert--india-signs-multilateral-convention-to-implement-tax-treaty-related-measures-toprevent-beps (accessed 16 September 2018).

Goel, A. (2017a) 'Modi government shifts India's corporate tax landscape amidst grim dispute resolution climate, The Wire [online] https://thewire.in/business/modi-government-shiftsindias-corporate-tax-landscape.

Goel, S. (2017b) A Case for MAP Arbitration in India, Kluwer International Tax Blog.

Hearson, M. (2015) The Tax Treaty Arbitrators Cometh [online] https://martinhearson.net/2015/09/ 21/the-tax-treaty-arbitrators-cometh/ (accessed 18 November 2018).

Information Brief (2015) OECD/G20 Base Erosion and Profit Shifting Project: 2015 Final Reports [online] https://www.oecd.org/ctp/beps-reports-2015-information-brief.pdf (accessed 22 November 2018).

Lang, M. and Owens, J. (2016) International Arbitration in Tax Matters, IBFD Publications, Amsterdam, the Netherlands.

Nishith Desai Associates (2017) India's MLI Positions: Impact on Availing Treaty Benefits [online] http://www.nishithdesai.com/fileadmin/user_upload/pdfs/NDA\%20Hotline/170704_H_TH_In dia_s-MLI-Position_WEB-2.pdf (accessed 14 November 2018).

Nishith Desai Associates (2018) Bilateral Investment Treaty Arbitration and India: With Special Focus on India Model BIT, 2016 [online] http://www.nishithdesai.com/fileadmin/user_upload/ pdfs/Research_Papers/Bilateral_Investment_Treaty_Arbitration_and_India-PRINT-2.pdf (accessed 21 March 2019).

OECD (2004) Improving the Process for Resolving International Tax Disputes [online] http://www.oecd.org/tax/treaties/33629447.pdf (accessed 11 January 2019).

OECD (2007a) Improving the Resolution of Tax Treaty Disputes [online] https://www.oecd.org/ctp/ dispute/38055311.pdf (accessed 21 February 2019).

OECD (2007b) Manual on Effective Mutual Agreement Procedures [online] https://www.oecd. org/ctp/38061910.pdf (accessed 18 March 2019).

OECD (2013) Action Plan on Base Erosion and Profit Shifting [online] https://www.oecd.org/ctp/ BEPSActionPlan.pdf (accessed 12 March 2019).

OECD (2014) BEPS Action 14: Make Dispute Resolution Mechanisms More Effective, Public Discussion Draft [online] https://www.oecd.org/ctp/dispute/discussion-draft-action-14-makedispute-resolution-mechanisms-more-effective.pdf (accessed 11 February 2019).

OECD (2016) BEPS Action 14 on More Effective Dispute Resolution Mechanism, Peer Review Documents [online] http://www.oecd.org/tax/beps/beps-action-14-on-more-effective-disputeresolution-peer-review-documents.pdf (accessed 10 March 2019).

OECD (2017) Multilateral Convention to Implement Tax Treaty Related Measures to Prevent BEPS [online] http://www.oecd.org/tax/treaties/multilateral-convention-to-implement-taxtreaty-related-measures-to-prevent-beps.htm (accessed 17 April 2019).

OECD (2017) Model Convention with Respect to Taxes on Income and on Capital (hereinafter 'Model Tax Convention'), Art 25: Mutual Agreement Procedure.

Oguttu, A.W. (2015) Resolving Double Tax Treaty Disputes: the Challenges of MAP with a Special Focus on Addressing Concerns of Developing Countries in Africa, South African Yearbook of International Law, No. 1 of 2015, pp.160-201. 
PwC (2017) Mutual Agreement Procedure: Answering Queries [online] https://www.pwc.in/assets/ $\mathrm{pdfs} /$ trs/transfer-pricing/2017/mutual-agreement-procedure-web-version.pdf (accessed 14 March 2019).

Ranjan, P. and Anand, P. (2018) 'Vodafone versus India-BIT by BIT, international arbitration becomes clearer', The Wire.

Rosenbloom, D. (2015) 'Tax disputes and the role of MAP and arbitration', Singapore Management University Conference [online] https://accountancy.smu.edu.sg/cet/tax-disputesand-role-map-and-arbitration.

Tran-Nam, B. and Walpole, M. (2016) 'Tax disputes, compliance costs and access to tax justice', International Conference on Tax Administration, University of New South Wales [online] https://www.business.unsw.edu.au/About-Site/Schools-Site/Taxation-Business-LawSite/Documents/Tax_disputes_compliance_costs.pdf.

United Nations Guide to the Mutual Agreement Procedure under Tax Treaties (2012) [online] http://www.un.org/esa/ffd/tax/gmap/Guide_MAP.pdf (accessed 17 May 2019).

Whitehead, S. (2017) The Tax Disputes and Litigation Review, 5th ed., pp.160-174, Law Business Research, London, England.

Zaimaj, A. (2014) 'Dispute avoidance and resolution', in Spies, K. and Petruzzi, R. (Eds.): Tax Policy Challenges in the 21st Century, p.273, Linde Verlag, Austria.

\section{Notes}

1 Dharmapala, D. (2014) What Do We Know about Base Erosion and Profit Shifting? A Review of the Empirical Literature, CESIFO Working Paper No. 4612, Leibniz Institute for Economic Research.

2 OECD (2013) Action Plan on Base Erosion and Profit Shifting [online] https://www.oecd.org/ ctp/BEPSActionPlan.pdf.

3 OECD (2017) Multilateral Convention to Implement Tax Treaty Related Measures to Prevent BEPS [online] http://www.oecd.org/tax/treaties/multilateral-convention-to-implement-taxtreaty-related-measures-to-prevent-beps.htm.

4 Information Brief, OECD/G20 Base Erosion and Profit Shifting Project: 2015 Final Reports [online] https://www.oecd.org/ctp/beps-reports-2015-information-brief.pdf.

5 OECD, Model Convention with Respect to Taxes on Income and on Capital (hereinafter 'Model Tax Convention'), Art 25: Mutual Agreement Procedure.

6 United Nations Guide to the Mutual Agreement Procedure under Tax Treaties (2012) [online] http://www.un.org/esa/ffd/tax/gmap/Guide_MAP.pdf.

7 OECD (2007b) Manual on Effective Mutual Agreement Procedures [online] https://www. oecd.org/ctp/38061910.pdf.

8 OECD (2016) BEPS Action 14 on More Effective Dispute Resolution Mechanism, Peer Review Documents [online] http://www.oecd.org/tax/beps/beps-action-14-on-more-effectivedispute-resolution-peer-review-documents.pdf.

9 OECD (2014) BEPS Action 14: Make Dispute Resolution Mechanisms more Effective, Public Discussion Draft [online] https://www.oecd.org/ctp/dispute/discussion-draft-action-14-makedispute-resolution-mechanisms-more-effective.pdf.

10 See supra note 5.

11 Deloitte (2016) OECD Issues Guidance on Action 14 Peer Reviews, Global Transfer Pricing Alert [online] https://www2.deloitte.com/content/dam/Deloitte/tw/Documents/tax/beps/twinternational-alert18.pdf. 
12 Tran-Nam, B. and Walpole, M. (2016) 'Tax disputes, compliance costs and access to tax justice', International Conference on Tax Administration, University of New South Wales [online] https://www.business.unsw.edu.au/About-Site/Schools-Site/Taxation-Business-LawSite/Documents/Tax_disputes_compliance_costs.pdf.

13 Oguttu, A.W. (2015) Resolving Double Tax Treaty Disputes: the Challenges of MAP with a Special Focus on Addressing Concerns of Developing Countries in Africa, South African Yearbook of International Law, No. 1 of 2015, pp.160-201.

14 Altman, Z.A. (2006) Dispute Resolution under Tax Treaties, IBFD Publications.

15 Id.

16 Lang, M. and Owens, J. (2016) International Arbitration in Tax Matters, IBFD Publications.

17 Id.

18 Arnold, B.J. (2015) An Introduction to Tax Treaties, United Nations Documents [online] http://www.un.org/esa/ffd/wp-content/uploads/2015/10/TT_Introduction_Eng.pdf.

19 OECD (2007a) Improving the Resolution of Tax Treaty Disputes [online] https://www.oecd. org/ctp/dispute/38055311.pdf.

20 See supra note 18.

21 OECD (2004) Improving the Process for Resolving International Tax Disputes [online] http://www.oecd.org/tax/treaties/33629447.pdf.

22 Zaimaj, A. (2014) 'Dispute avoidance and resolution', in Spies, K. and Petruzzi, R. (Eds.): Tax Policy Challenges in the 21st Century, p.273.

23 Hearson, M. (2015) The Tax Treaty Arbitrators Cometh [online] https://martinhearson.net/ 2015/09/21/the-tax-treaty-arbitrators-cometh/.

24 See supra note 5.

25 Cheng, T-H. and Entchev, I. (2014) 'State incapacity and sovereign immunity in international arbitration', Singapore Academy of Law Journal.

26 Committee of Experts on International Cooperation in Tax Matters, Tenth Session (2015) UN Secretariat Paper on Alternative Dispute Resolution in Taxation [online] http://www.un.org/ esa/ffd/wp-content/uploads/2015/10/11STM_CRP8_DisputeResolution.pdf.

27 Id.

28 See supra note 12 at p.29.

29 Bakker, A. and Levey, M.M. (2011) Transfer Pricing and Dispute Resolution, IBFD.

30 Whitehead, S., The Tax Disputes and Litigation Review, 5th ed., pp.160-174, Law Business Research.

31 Pwc (2017) Mutual Agreement Procedure: Answering Queries [online] https://www.pwc.in/ assets/pdfs/trs/transfer-pricing/2017/mutual-agreement-procedure-web-version.pdf.

32 Goel, S. (2017b) A Case for MAP Arbitration in India, Kluwer International Tax Blog.

33 At the group of twenty meeting held in Cairns, Australia on 20-21 September 2014, Nirmala Sitaraman, India's then Minister of Finance, expressed reservations on introducing a mandatory, binding MAP arbitration in India's tax treaties.

34 See supra note 24.

35 EY Global Tax Alert (2017) India Signs Multilateral Convention to Implement Tax Treaty Related Measures to prevent BEPS.

36 See supra note 24.

37 Rosenbloom, D. (2015) 'Tax disputes and the role of MAP and arbitration', Singapore Management University Conference [online] https://accountancy.smu.edu.sg/cet/tax-disputesand-role-map-and-arbitration. 
38 Dasgupta, A. and Thakurta, P.G. (2018) The Vodafone Tax Saga and India's Arbitration Worries.

39 Ranjan, P. and Anand, P. (2018) 'Vodafone versus India-BIT by BIT, international arbitration becomes clearer', The Wire.

40 Goel, A. (2017a) 'Modi government shifts India's corporate tax landscape amidst grim dispute resolution climate', The Wire [online] https://thewire.in/business/modi-government-shiftsindias-corporate-tax-landscape.

41 Nishith Desai Associates (2017) India's MLI Positions: Impact on Availing Treaty Benefits [online] http://www.nishithdesai.com/fileadmin/user_upload/pdfs/NDA\%20Hotline/170704_ H_TH_India_s-MLI-Position_WEB-2.pdf.

42 Nishith Desai Associates (2018) Bilateral Investment Treaty Arbitration and India: With Special Focus on India Model BIT, 2016 [online] http://www.nishithdesai.com/fileadmin/user upload/pdfs/Research_Papers/Bilateral_Investment_Treaty_Arbitration_and_India-PRINT$\overline{2}$.pdf. 